\title{
The Physical Activity, Sedentary Behaviour and Sleep (PASS) Indicator Framework
}

\author{
Karen C. Roberts, MSc; Gregory Butler, MSc; Brenda Branchard; Deepa P. Rao, PhD; Victoria Otterman, BA; \\ Wendy Thompson, MSc; Gayatri Jayaraman, PhD
}

The Physical Activity, Sedentary Behaviour and Sleep (PASS) Indicator Framework is being released in this issue of Health Promotion and Chronic Disease Prevention in Canada (HPCDP).

\section{Background}

Physical activity surveillance in Canada has traditionally focussed on measuring and reporting on the most active end of the activity spectrum. Emerging research suggests that in addition to insufficient moderate-to-vigorous physical activity (MVPA), sedentary behaviour and inadequate sleep are also important risk factors for chronic disease. In order to create effective public health policy and program initiatives to target all levels of activity (MVPA, light physical activity, sedentary behaviour and sleep), the demand for reliable, nationally representative data and information on the patterns of all of these behaviours among Canadians has increased. As a result, the need for a broader, modernized approach to national physical activity surveillance, with the inclusion of sedentary behaviour, sleep and the proximal and distal factors that impact all of these behaviours, was identified as a priority for the Public Health Agency of Canada (PHAC) in 2014.

An important first step in modernizing PHAC's surveillance approach was the development of an indicator framework to identify and systematically organize key indicators for routine reporting. The PASS Indicator Framework was informed by the research literature and developed through an iterative, consultative process with scientific experts and policy and program makers from across the country at various levels of government. In its final form, containing 55 unique indicators, the PASS Indicator Framework provides comprehensive, high quality information on the outcomes and risk and protective factors related to physical activity, sedentary behaviour and sleep for Canadian adults (aged 18+; see Table 1), children (aged 5-11 years; see Table 2) and youth (aged 12-17; see Table 2). The PASS Indicator Framework is centred around a conceptual model that incorporates a socioecological approach-addressing outcomes and factors at the individual and broader social and built-environment levels. It provides surveillance indicators and measures as well as calculated estimates using traditional and nontraditional data sources. Its target audience is key stakeholders such as provincial, territorial and regional public health officials as well as the federal Health Portfolio and other relevant government departments, organizations, ministries and public health units.

The PASS Indicators will be made publicly available on the PHAC Public Health Infobase website (infobase.phac-aspc.gc.ca) through an interactive data tool alongside the Canadian Chronic Disease Indicators and the Positive Mental Health Surveillance Indicator Framework. The interactive data tool can be used to monitor trends over time and offers the ability to break data down by key variables; it will support PHAC and stakeholders in targeting and monitoring intervention strategies. This issue of the HPCDP Journal contains the first Quick Stats documents containing the PASS Indicators.

\section{Future work}

The PASS Indicators are evergreen. Although measures and data exist to report on many indicators identified within the Indicator Framework, there are still gaps, especially at the environmental levels. Active enhancement and data development using surveys and nontraditional data sources, including administrative databases, is currently underway, as is targeted research and surveillance to address these data gaps. 
TABLE 1

PHYSICAL ACTIVITY, SEDENTARY BEHAVIOUR AND SLEEP (PASS) INDICATORS QUICK STATS, ADULTS (AGED 18+), CANADA, 2017 EDITION

\begin{tabular}{|c|c|c|c|c|}
\hline INDICATOR GROUP & INDICATOR(S) & MEASURE(S) & LATEST DATA & $\begin{array}{l}\text { DATA SOURCE } \\
\text { (YEAR) }\end{array}$ \\
\hline \multicolumn{5}{|l|}{ PHYSICAL ACTIVITY } \\
\hline \multirow[t]{12}{*}{ Individual } & $\begin{array}{l}\text { Physical activity guideline } \\
\text { adherence }\end{array}$ & $\begin{array}{l}\% \text { of adults aged } 18 \text { to } 79 \text { years who meet physical activity guidelines } \\
\text { by accumulating at least } 150 \text { minutes of moderate-to-vigorous } \\
\text { physical activity each week, in bouts of } 10 \text { minutes or more }\end{array}$ & $17.5 \%$ & $\begin{array}{r}\text { CHMS } \\
(2014-2015)\end{array}$ \\
\hline & $\begin{array}{l}\text { Occupational physical activity } \\
\text { and active chores amount }\end{array}$ & $\begin{array}{l}\text { Average number of hours per week adults report doing physical } \\
\text { activities while at work, in or around their home or while volunteering }\end{array}$ & 2.9 hours & CCHS (2015) \\
\hline & $\begin{array}{l}\text { Leisure time physical activity } \\
\text { amount }\end{array}$ & $\begin{array}{l}\text { Average number of hours per week adults report doing sports, } \\
\text { fitness or recreational physical activities, organized or non-orga- } \\
\text { nized, that lasted a minimum of } 10 \text { continuous minutes }\end{array}$ & 1.8 hours & CCHS (2015) \\
\hline & Sports participation amount & $\begin{array}{l}\% \text { of population aged } 15 \text { or older who reported regularly } \\
\text { participating in any sports during the past } 12 \text { months }\end{array}$ & $26.0 \%$ & GSS (2010) \\
\hline & \multirow[t]{2}{*}{ Active travel amount } & $\%$ of adults who report walking or cycling to work or school & $21.8 \%$ & CCHS (2014) \\
\hline & & $\begin{array}{l}\text { Average number of hours per week adults report using active } \\
\text { ways like walking or cycling to get to places }\end{array}$ & 1.7 hours & CCHS (2015) \\
\hline & Intention level & $\begin{array}{l}\% \text { of adults who, when thinking about the next six months, } \\
\text { intend to be physically active }\end{array}$ & $73.9 \%$ & $\begin{array}{r}\text { PAM } \\
(2014-2015)\end{array}$ \\
\hline & Enjoyment level & $\%$ of adults who report that physical activity is generally pleasant & $87.0 \%$ & $\begin{array}{r}\text { PAM } \\
(2014-2015)\end{array}$ \\
\hline & Confidence level & $\begin{array}{l}\% \text { of adults who report they are confident that they could } \\
\text { regularly do a total of } 30 \text { minutes or more of moderate physical } \\
\text { activity three or four times a week }\end{array}$ & $67.0 \%$ & $\begin{array}{r}\text { PAM } \\
(2014-2015)\end{array}$ \\
\hline & Physical literacy & \multicolumn{3}{|l|}{ In development } \\
\hline & Physical health status & $\%$ of adults who report their health is "very good" or "excellent" & $61.1 \%$ & CCHS (2015) \\
\hline & Mental health status & $\begin{array}{l}\% \text { of adults who report their mental health is "very good" or } \\
\text { "excellent" }\end{array}$ & $72.1 \%$ & CCHS (2015) \\
\hline \multirow[t]{3}{*}{$\begin{array}{l}\text { Family/social } \\
\text { environment }\end{array}$} & $\begin{array}{l}\text { Level of peer and spousal } \\
\text { support }\end{array}$ & \multicolumn{3}{|l|}{ In development } \\
\hline & Community norms & \multicolumn{3}{|l|}{ In development } \\
\hline & $\begin{array}{l}\text { Presence and type of barriers } \\
\text { for physical activity }\end{array}$ & \multicolumn{3}{|l|}{ In development } \\
\hline \multirow{6}{*}{$\begin{array}{l}\text { Built/society } \\
\text { environment }\end{array}$} & Community walkability & \multicolumn{3}{|l|}{ In development } \\
\hline & $\begin{array}{l}\text { Presence of parks and } \\
\text { recreation facilities }\end{array}$ & $\begin{array}{l}\text { \% of adults who "somewhat agree" or "strongly agree" that their } \\
\text { neighbourhood has several free or low cost recreation facilities, } \\
\text { such as parks, walking trails, bike paths, recreation centres, } \\
\text { playgrounds, public swimming pools, etc. }\end{array}$ & $78.1 \%$ & CCHS RR (2011) \\
\hline & $\begin{array}{l}\text { Presence of active transport } \\
\text { infrastructure }\end{array}$ & $\begin{array}{l}\% \text { of adults who report their community has infrastructure that } \\
\text { supports walking or biking (well-maintained sidewalks or } \\
\text { designated areas for biking) }\end{array}$ & $78.2 \%$ & CCHS RR (2011) \\
\hline & Shower access at work & $\begin{array}{l}\% \text { of adults aged } 18 \text { to } 75 \text { who report having access to showers or } \\
\text { change rooms at or near work }\end{array}$ & $45.6 \%$ & $\begin{array}{r}\text { CCHS } \\
(2007-2008)\end{array}$ \\
\hline & $\begin{array}{l}\text { Community spending on } \\
\text { sports and recreation programs }\end{array}$ & \multicolumn{3}{|l|}{ In development } \\
\hline & $\begin{array}{l}\text { Community spending on } \\
\text { active transportation plans }\end{array}$ & \multicolumn{3}{|l|}{ In development } \\
\hline \multicolumn{5}{|c|}{ SEDENTARY BEHAVIOUR } \\
\hline \multirow[t]{5}{*}{ Individual } & Total sedentary time amount & $\begin{array}{l}\text { Average number of hours per day spent sedentary, excluding } \\
\text { sleep time, population aged } 18 \text { to } 79 \text { years }\end{array}$ & 9.6 hours & $\begin{array}{r}\text { CHMS } \\
(2014-2015)\end{array}$ \\
\hline & $\begin{array}{l}\text { Recreational screen time } \\
\text { amount }\end{array}$ & $\begin{array}{l}\text { Average number of hours per week adults aged } 18 \text { to } 79 \text { years } \\
\text { report spending on a computer or tablet, e.g. watching videos, } \\
\text { playing computer games, emailing or surfing the Internet }\end{array}$ & 25.0 hours & $\begin{array}{r}\text { CHMS } \\
(2014-2015)\end{array}$ \\
\hline & $\begin{array}{l}\text { Workplace sedentary time } \\
\text { amount }\end{array}$ & \multicolumn{3}{|l|}{ In development } \\
\hline & Non-active travel amount & \multicolumn{3}{|l|}{ In development } \\
\hline & Awareness level & \multicolumn{3}{|l|}{ In development } \\
\hline \multirow[t]{2}{*}{$\begin{array}{l}\text { Family/social } \\
\text { environment }\end{array}$} & $\begin{array}{l}\text { Presence and type of barriers } \\
\text { for reducing sedentary } \\
\text { behaviour }\end{array}$ & \multicolumn{3}{|l|}{ In development } \\
\hline & $\begin{array}{l}\text { Work sedentary behaviour } \\
\text { norms }\end{array}$ & \multicolumn{3}{|l|}{ In development } \\
\hline $\begin{array}{l}\text { Built/society } \\
\text { environment }\end{array}$ & Supportive work policies & \multicolumn{3}{|l|}{ In development } \\
\hline
\end{tabular}




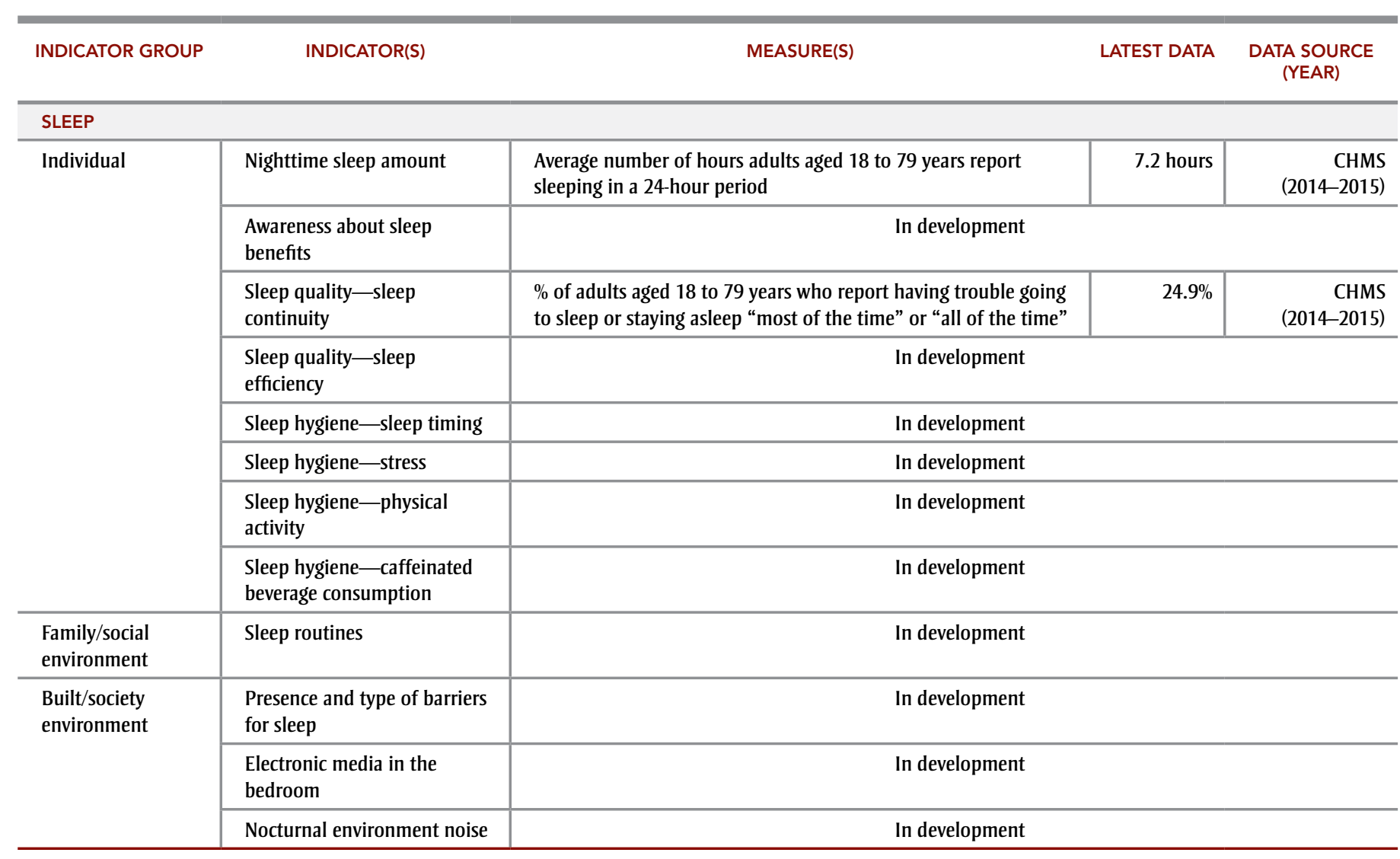

Abbreviations: CCHS, Canadian Community Health Survey; CCHS RR, Canadian Community Health Survey Rapid Response; CHMS, Canadian Health Measures Survey; GSS, General Social Survey; PAM, Physical Activity Monitor.

Note: "In development" refers to measures that are under development either because a data source is currently not available or because more research has to be done to identify a promising measure and data source.

Correspondence: Behaviours, Environments and Lifespan Team, Centre for Surveillance and Applied Research, Public Health Agency of Canada, 785 Carling Avenue, Ottawa, ON K1A 0K9 Email: chronic.publications.chroniques@phac-aspc.gc.ca

Suggested citation: Public Health Agency of Canada. Physical Activity, Sedentary Behaviour and Sleep (PASS) Indicators: Quick Stats, adults (aged 18+), Canada, 2017 edition. Ottawa (ON): Public Health Agency of Canada; 2017.

Visit the Physical Activity, Sedentary Behaviour and Sleep Indicators online: http://infobase.phac-aspc.gc.ca/ 
TABLE 2

PHYSICAL ACTIVITY, SEDENTARY BEHAVIOUR AND SLEEP (PASS) INDICATORS

\section{QUICK STATS, CHILDREN (AGED 5 TO 11) AND YOUTH (AGED 12 TO 17), CANADA, 2017 EDITION}

\begin{tabular}{|c|c|c|c|c|}
\hline INDICATOR GROUP & INDICATOR(S) & MEASURE(S) & LATEST DATA & $\begin{array}{l}\text { DATA SOURCE } \\
\text { (YEAR) }\end{array}$ \\
\hline \multicolumn{5}{|l|}{ PHYSICAL ACTIVITY } \\
\hline \multirow[t]{17}{*}{ Individual } & $\begin{array}{l}\text { Physical activity recommenda- } \\
\text { tion adherence }\end{array}$ & $\begin{array}{l}\% \text { of children and youth who meet physical activity recommenda- } \\
\text { tions by accumulating at least } 60 \text { minutes of moderate-to-vigorous } \\
\text { physical activity per day }\end{array}$ & $37.6 \%$ & $\begin{array}{r}\text { CHMS } \\
(2014-2015)\end{array}$ \\
\hline & $\begin{array}{l}\text { Total moderate-to-vigorous } \\
\text { physical activity amount }\end{array}$ & $\begin{array}{l}\text { Average number of minutes per day children and youth are engaged } \\
\text { in moderate-to-vigorous physical activity }\end{array}$ & 57.0 minutes & $\begin{array}{r}\text { CHMS } \\
(2014-2015)\end{array}$ \\
\hline & 24-hour movement & $\begin{array}{l}\% \text { of children and youth who meet the Canadian 24-Hour } \\
\text { Movement Guidelines for Children and Youth }\end{array}$ & $9.5 \%$ & $\begin{array}{r}\text { CHMS } \\
(2014-2015)\end{array}$ \\
\hline & \multirow[t]{2}{*}{$\begin{array}{l}\text { School physical activity } \\
\text { amount }\end{array}$} & $\begin{array}{l}\text { Average number of hours per week youth in Grades } 6 \text { to } 10 \text { report } \\
\text { taking part in physical activity that makes them out of breath or } \\
\text { warmer than usual during class time at school }\end{array}$ & 2.3 hours & $\begin{array}{r}\text { HBSC } \\
(2014-2015)\end{array}$ \\
\hline & & $\begin{array}{l}\text { Average number of hours per week that parents report children } \\
\text { spend doing physical activity during class time }\end{array}$ & 2.0 hours & $\begin{array}{r}\text { CHMS } \\
(2014-2015)\end{array}$ \\
\hline & $\begin{array}{l}\text { Sports participation amount } \\
\text { (leisure time) }\end{array}$ & $\begin{array}{l}\% \text { of Canadian parents who report that their children participated } \\
\text { in sports in the last } 12 \text { months }\end{array}$ & $74.2 \%$ & $\begin{array}{r}\text { PAM } \\
(2014-2015)\end{array}$ \\
\hline & $\begin{array}{l}\text { Active play amount (leisure } \\
\text { time) }\end{array}$ & $\begin{array}{l}\% \text { of children who accumulate } 3 \text { hours or less per week of active } \\
\text { play (unstructured physical activity) outside of school }\end{array}$ & $48.8 \%$ & $\begin{array}{r}\text { CHMS } \\
(2014-2015)\end{array}$ \\
\hline & \multirow[t]{2}{*}{ Active travel amount } & $\%$ of youth who report walking or cycling to work or school & $53.0 \%$ & CCHS (2014) \\
\hline & & $\begin{array}{l}\text { Average amount of hours per week youth report using active ways } \\
\text { like walking or cycling to get to places }\end{array}$ & 3.3 hours & CCHS (2015) \\
\hline & Intention level & \multicolumn{3}{|l|}{ In development } \\
\hline & Enjoyment level & $\%$ of youth who report they enjoy being physically active & \multicolumn{2}{|c|}{ In development } \\
\hline & Confidence level & $\begin{array}{l}\% \text { of youth who report they are confident in their ability to be } \\
\text { physically active }\end{array}$ & \multicolumn{2}{|c|}{ In development } \\
\hline & Physical literacy & \multicolumn{3}{|l|}{ In development } \\
\hline & \multirow[t]{2}{*}{ Physical health status } & $\%$ of youth who report their health is "very good" or "excellent" & $72.6 \%$ & CCHS (2015) \\
\hline & & $\begin{array}{l}\text { \% of parents who report the health of their child is "very good" or } \\
\text { "excellent" }\end{array}$ & $88.4 \%$ & $\begin{array}{r}\text { CHMS } \\
(2014-2015)\end{array}$ \\
\hline & \multirow[t]{2}{*}{ Mental health status } & $\begin{array}{l}\text { \% of youth who report their mental health is "very good" or } \\
\text { "excellent" }\end{array}$ & $73.9 \%$ & $\begin{array}{r}\text { CHMS } \\
(2014-2015)\end{array}$ \\
\hline & & $\begin{array}{l}\% \text { of parents who report their child's mental health is "very good" } \\
\text { or "excellent" }\end{array}$ & \multicolumn{2}{|c|}{ In development } \\
\hline \multirow[t]{2}{*}{$\begin{array}{l}\text { Family/social } \\
\text { environment }\end{array}$} & Level of parental support & $\begin{array}{l}\% \text { of Canadian parents who report "often" or "very often" playing } \\
\text { active games with their children in the past year }\end{array}$ & $36.1 \%$ & $\begin{array}{r}\text { PAM } \\
(2014-2015)\end{array}$ \\
\hline & Level of peer support & $\begin{array}{l}\% \text { of youth in Grades } 9 \text { and } 10 \text { who report that most of their friends } \\
\text { "often" participate in organized sports activities with others }\end{array}$ & $58.2 \%$ & HBSC (2014) \\
\hline \multirow{8}{*}{$\begin{array}{l}\text { Built/society } \\
\text { environment }\end{array}$} & Perceived distance to school & \multicolumn{3}{|l|}{ In development } \\
\hline & Level of community safety & $\begin{array}{l}\% \text { of Canadian parents who identify safety concerns as a barrier to } \\
\text { children's physical activity }\end{array}$ & $24.0 \%$ & $\begin{array}{r}\text { PAM } \\
(2014-2015)\end{array}$ \\
\hline & Community walkability & \multicolumn{3}{|l|}{ In development } \\
\hline & $\begin{array}{l}\text { Presence of parks and } \\
\text { recreation facilities }\end{array}$ & $\begin{array}{l}\text { \% of youth who "somewhat agree" or "strongly agree" that their } \\
\text { neighbourhood has several free or low cost recreation facilities, } \\
\text { such as parks, walking trails, bike paths, recreation centres, } \\
\text { playgrounds, public swimming pools, etc. }\end{array}$ & $79.2 \%$ & CCHS RR (2011) \\
\hline & $\begin{array}{l}\text { Presence of active transport } \\
\text { infrastructure }\end{array}$ & \multicolumn{3}{|l|}{ In development } \\
\hline & Supportive policies at school & $\begin{array}{l}\% \text { of schools that have a committee that oversees policies and } \\
\text { practices concerning physical activity (e.g. health action team) }\end{array}$ & $42.3 \%$ & $\begin{array}{r}\text { HBSC } \\
\text { (2014- Admin) }\end{array}$ \\
\hline & $\begin{array}{l}\text { Community spending on } \\
\text { sports and recreation } \\
\text { programs }\end{array}$ & \multicolumn{3}{|l|}{ In development } \\
\hline & $\begin{array}{l}\text { Community spending on } \\
\text { active transportation plans }\end{array}$ & \multicolumn{3}{|l|}{ In development } \\
\hline
\end{tabular}




\begin{tabular}{|c|c|c|c|c|}
\hline INDICATOR GROUP & INDICATOR(S) & MEASURE(S) & LATEST DATA & $\begin{array}{c}\text { DATA SOURCE } \\
\text { (YEAR) }\end{array}$ \\
\hline \multicolumn{5}{|c|}{ SEDENTARY BEHAVIOUR } \\
\hline \multirow[t]{5}{*}{ Individual } & $\begin{array}{l}\text { Sedentary behaviour } \\
\text { recommendation adherence }\end{array}$ & $\begin{array}{l}\% \text { of children and youth who report meeting sedentary behaviour } \\
\text { recommendations by spending } 2 \text { hours or less per day watching } \\
\text { television or using a computer during leisure time }\end{array}$ & $28.5 \%$ & $\begin{array}{r}\text { CHMS } \\
(2014-2015)\end{array}$ \\
\hline & $\begin{array}{l}\text { Recreational screen time } \\
\text { amount }\end{array}$ & $\begin{array}{l}\text { Average number of hours per week youth report spending on a } \\
\text { computer or tablet, e.g. watching videos, playing computer games, } \\
\text { emailing or surfing the Internet }\end{array}$ & 4.2 hours & $\begin{array}{r}\text { CHMS } \\
(2014-2015)\end{array}$ \\
\hline & Sedentary time at school & \multicolumn{3}{|l|}{ In development } \\
\hline & Non-active travel amount & \multicolumn{3}{|l|}{ In development } \\
\hline & Time spent outdoors & Average number of hours per day children spend outside & 1.8 hours & $\begin{array}{r}\text { CHMS } \\
(2014-2015)\end{array}$ \\
\hline \multirow{2}{*}{$\begin{array}{l}\text { Family/social } \\
\text { environment }\end{array}$} & Parental awareness level & \multicolumn{3}{|l|}{ In development } \\
\hline & Home screen time rules & \multicolumn{3}{|l|}{ In development } \\
\hline $\begin{array}{l}\text { Built/society } \\
\text { environment }\end{array}$ & $\begin{array}{l}\text { Presence of and access to } \\
\text { electronic media }\end{array}$ & \multicolumn{3}{|l|}{ In development } \\
\hline \multicolumn{5}{|l|}{ SLEEP } \\
\hline \multirow[t]{10}{*}{ Individual } & $\begin{array}{l}\text { Sleep recommendation } \\
\text { adherence }\end{array}$ & $\begin{array}{l}\% \text { of children and youth who report meeting sleep recommenda- } \\
\text { tions by obtaining adequate sleep: } 9 \text { to } 11 \text { hours per night for ages } \\
5 \text { to } 13 \text { years and } 8 \text { to } 10 \text { hours per night for ages } 14 \text { to } 17\end{array}$ & $70.7 \%$ & $\begin{array}{r}\text { CHMS } \\
(2014-2015)\end{array}$ \\
\hline & $\begin{array}{l}\text { Amount of sleep in 24-hour } \\
\text { period }\end{array}$ & $\begin{array}{l}\text { Average number of hours children and youth report sleeping in a } \\
\text { 24-hour period }\end{array}$ & 9.0 hours & $\begin{array}{r}\text { CHMS } \\
(2014-2015)\end{array}$ \\
\hline & $\begin{array}{l}\text { Daytime napping amount ( } 5 \\
\text { years and under) }\end{array}$ & \multicolumn{3}{|l|}{ In development } \\
\hline & Nighttime sleep amount & \multicolumn{3}{|l|}{ In development } \\
\hline & $\begin{array}{l}\text { Sleep quality—sleep } \\
\text { continuity }\end{array}$ & $\begin{array}{l}\% \text { of children and youth who report having trouble going to sleep } \\
\text { or staying asleep "most of the time" or "all of the time" }\end{array}$ & $10.4 \%$ & $\begin{array}{r}\text { CHMS } \\
(2014-2015)\end{array}$ \\
\hline & $\begin{array}{l}\text { Sleep quality—sleep } \\
\text { efficiency }\end{array}$ & \multicolumn{3}{|l|}{ In development } \\
\hline & Sleep hygiene—sleep timing & \multicolumn{3}{|l|}{ In development } \\
\hline & Sleep hygiene—-stress & \multicolumn{3}{|l|}{ In development } \\
\hline & $\begin{array}{l}\text { Sleep hygiene—physical } \\
\text { activity }\end{array}$ & \multicolumn{3}{|l|}{ In development } \\
\hline & $\begin{array}{l}\text { Sleep hygiene—caffeinated } \\
\text { beverage consumption }\end{array}$ & \multicolumn{3}{|l|}{ In development } \\
\hline $\begin{array}{l}\text { Family/social } \\
\text { environment }\end{array}$ & Home sleep rules and routines & $\begin{array}{l}\% \text { of parents who report they set regular bedtimes for their children } \\
\text { and enforce them }\end{array}$ & In dev & opment \\
\hline \multirow[t]{2}{*}{$\begin{array}{l}\text { Built/society } \\
\text { environment }\end{array}$} & $\begin{array}{l}\text { Electronic media in the } \\
\text { bedroom }\end{array}$ & $\begin{array}{l}\% \text { of children and youth who report they have a television, } \\
\text { computer or game console in their bedroom }\end{array}$ & In dev & opment \\
\hline & Nocturnal environment noise & \multicolumn{3}{|l|}{ In development } \\
\hline
\end{tabular}

Abbreviations: CCHS, Canadian Community Health Survey; CCHS RR, Canadian Community Health Survey Rapid Response; CHMS, Canadian Health Measures Survey; HBSC, Health Behaviours in School-aged Children; HBSC-Admin, Health Behaviours in School-aged Children Administrator Survey; PAM, Physical Activity Monitor.

Note: "In development" refers to measures that are under development either because a data source is currently not available or because more research has to be done to identify a promising measure and data source.

Correspondence: Behaviours, Environments and Lifespan Team, Centre for Surveillance and Applied Research, Public Health Agency of Canada, 785 Carling Avenue, Ottawa, ON K1A 0K9; Email: chronic.publications.chroniques@phac-aspc.gc.ca

Suggested citation: Public Health Agency of Canada. Physical Activity, Sedentary Behaviour and Sleep (PASS) Indicators: Quick Stats, children (aged 5 to 11) and youth (aged 12 to 17), Canada, 2017 edition. Ottawa (ON): Public Health Agency of Canada; 2017.

Visit the Physical Activity, Sedentary Behaviour and Sleep Indicators online: http://infobase.phac-aspc.gc.ca/ 